\title{
SURVEI KESEHATAN TELINGA PADA ANAK PASAR BERSEHATI KOMUNITAS DINDING MANADO
}

\author{
${ }^{1}$ Kurniati Mappadang \\ ${ }^{2}$ Julied Dehoop \\ ${ }^{2}$ Steward K. Mengko
}

\author{
${ }^{1}$ Kandidat Skripsi Fakultas Kedokteran Universitas Sam Ratulangi Manado \\ ${ }^{2}$ Bagian/SMF Telinga Hidung Tenggorok-Bedah Kepala Leher Fakultas Kedokteran \\ Universitas Sam Ratulangi Manado \\ Email: kmappadang11_205@yahoo.com
}

\begin{abstract}
Ears are one of the most important organs in human body, we got 20\% information from both ears daily. When something wrong happens, the process of receiving information will be interrupted. The purpose of this research is to collect the data by doing survey about ears health of the children in Komunitas Dinding Manado. This research used the observational descriptive method with cross sectional approach. Total respondens of the research are 33 persons. The data have been collected by doing examination of meatus austikus external by doctors of T.H.T.K.L. then processed by using Microsoft Excel 2010. The result showed there are 18 kids have cerumen in the right ear and 19 kids in the left ear. While for the ears aperture examination, 2 kids got secret in the right ear, and 1 kid for the left ear. Then in membrane timpani examination, there are 4 kids got perforation in the right ear while 3 kids got it on their left ear. Conclusion: Most of results on respondens are normal

Keywords: health survey, ears examination
\end{abstract}

\begin{abstract}
Abstrak: Telinga merupakan salah satu alat indra yang penting, dari indra pendengaran kita menyerap sebesar $20 \%$ informasi dari kehidupan sehari-hari. Jika terdapat gangguan pada indra pendengaran maka proses penerimaan informasi tersebut akan pula terganggu. Tujuan penelitan ini yaitu untuk mendapatkan data survei mengenai gambaran kesehatan telinga pada anak-anak di Pasar Bersehati Komunitas Dinding Manado. Penelitian ini merupakan jenis penelitian deskriptif observasional, dengan pendekatan cross sectional. Sampel penelitian sebanyak 33 orang. Pengambilan data dilakukan dengan pemeriksaan meatus austikus eksterna oleh dokter spesialis bagian T.H.T.K.L. kemudian di olah dengan menggunakan Mikrosoft excel 2010. Hasil penelitian didapatkan hasil terbanyak adalah serumen pada 18 orang di telinga kanan dan serumen telinga kiri sebanyak 19 orang. Pada pemeriksaan liang telinga juga didapatkan sekret telinga kanan pada 2 orang serta sekret telinga kiri pada 1 orang. Pada pemeriksaaan membran timpani ini ditemukan perforasi telinga kanan sebanyak 4 orang dan perforasi telinga kiri sebanyak 3 orang. Simpulan: Sebagian besar hasil pada responden penelitian adalah normal.
\end{abstract}

Kata kunci: survei kesehatan, pemeriksaan telinga

Telinga merupakan salah satu alat indra yang penting dan mempunyai peran yang besar dalam kehidupan sehari-hari. Dari indra pendengaran kita menyerap sebesar $20 \%$ informasi yang disampaikan dibanding dengan membacanya yang hanya dapat menyerap informasi sebesar $10 \%{ }^{1}$ Jika terdapat gangguan pada indra pendengaran maka proses penerimaan informasi akan pula terganggu.

Gangguan pendengaran merupakan defisit sensorik yang paling sering pada 
populasi manusia, mempengaruhi lebih dari 250 juta orang di dunia.Survei yang dilaksanakan di 7 (tujuh) provinsi di Indonesia menunjukkan prevalensi ketulian $0,4 \%$ morbiditas telinga $18,5 \%$. Penyakit telinga luar (6,8\%), penyakit telinga tengah (3,9 \%), dan presbikusis (2,6\%). Penyebab terbanyak dari morbiditas telinga adalah serumen prob (3,6\%) dan penyebab terbanyak morbiditas telinga tengah adalah otitis media supurativa kronik (OMSK) tipe jinak (3,0\%). ${ }^{2}$

Prevalensi morbiditas telinga paling tinggi pada kelompok usia sekolah (7-18 tahun), di samping serumen prop dan OMSK tipe jinak, angka ketulian pada kelompok umur balita ) 0-4 tahun sebesar $0,4 \%$ juga lebih tinggi dibandingkan dengan kelompok umur prasekolah dan sekolah. $^{2}$

Survei yang juga dilakukan oleh profesi perhati dan departemen Mata FKUI prevalensi serumen prop pada anak anak usia sekolah cukup tinggi., sumbatan serumen ini dapat mengakibatkan gangguan pendengaran. Gangguan pendengaran pada seorang anak akan menunjukkan 3 hal penting, yaitu kelainan perkembangan, menurunnya hasil belajar, dan kesulitan dalam penyesuaian pergaulan. ${ }^{1}$

Komunitas dinding merupakan suatu komunitas yang mengumpulkan anak-anak dari pedagang kecil di sekitar pasar Bersehati Manado dan melaksanakan berbagai program kegiatan salah satunya adalah kegiatan belajar mengajar. ${ }^{3}$ Anak dalam komunitas ini terutama anak di usia balita, prasekolah dan sekolah dan merupakan golongan ekonomi rendah dengan pengetahuan dan perilaku kesehatan yang masih kurang.

Hal tersebut perlu mendapat perhatian khusus mengingat pada usia ini merupakan masa kritis dari perkembangan berbicara dan berbahasa. Angka kejadian ini dapat diturunkan melalui deteksi dini gangguan pendengaran. ${ }^{2}$

Berdasarkan uraian diatas maka peneliti tertarik untuk mengadakan penelitian dengan judul Survei Kesehatan
Telinga Pada Anak Anak Pasar Bersehati Komunitas Dinding Manado dengan tujuan untuk melihat tingkat kesehatan telinga pada anak anak di tempat ini.

\section{METODE PENELITIAN}

Penelitian ini merupakan jenis penelitian deskriptif observasional, dengan pendekatan cross sectional. Penelitian ini dilaksanakan di pasar Bersehati Kelurahan Calaca, Kecamatan Wanea kota Manado tepatnya di Komunitas Dinding Manado. Penelitiandilaksanakan pada bulan November 2014. Populasi adalah anak anak Komunitas Dinding Manado dengan sampel penelitian adalah anak anak yang bersedia melakukan pemeriksaan T.H.TK.L. Variabel penelitian penelitian yaitu jenis kelamin dan gangguan/kelainan pada telinga.

Pengambilan data penelitian
dilakukan melalui wawancara dan pemeriksaan meatus austikus eksternus dengan menggunakan alat seperti lampu kepala, spekulum telinga, dan otoskop. Pemeriksaan ini menilai gangguan/ kelainan pada daun telinga, liang telinga dan membran timpani. Data kemudian diolah menggunakan Microsoft excel 2010.

\section{HASIL PENELITIAN}

Sampel penelitian berjumlah 33 anak yang berumur dari dua sampai tujuh belas tahun. Sampel tersebut terdiri dari 19 perempuan (57,6\%). dan 14 lakilaki (42,4 $\%)$.

\section{a. Daun Telinga}

Pada pemeriksaan daun telinga anak anak pasar Bersehati Komunitas Dinding Manado didapatkan semua normal dan tidak didapatkan hasil yang abnormal. Data dapat dilihat pada tabel berikut

b. Liang Telinga

Pada pemeriksaan liang telinga anak anak pasar Bersehati Komunitas Dinding Manado didapatkan hasil terbanyak adalah serumen pada 18 orang (54.5 \%) di telinga kanan dan serumen telinga kiri sebanyak 19 orang 
(57.6\%), lapang telinga kanan dan lapang telinga kiri sebanyak 13 orang (39.4\%), dan ditemukan sekret telinga kanan pada 2 orang (6.1\%) dan sekret telinga kiri pada 1 orang (3.0\%) (Tabel 2).

Tabel 1. Distribusi hasil pemeriksaan daun telinga

\begin{tabular}{lllll} 
& & & \multicolumn{2}{c}{$\%$} \\
\cline { 2 - 5 } $\begin{array}{l}\text { Keadaan } \\
\text { daun } \\
\text { telinga }\end{array}$ & kanan & kiri & kanan & kiri \\
\hline normal & 33 & 33 & 100 & 100 \\
\hline abnormal & 0 & 0 & 0 & 0 \\
\hline total & 33 & 33 & 100 & 100
\end{tabular}

Tabel 2. Distribusi hasil pemeriksaan liang telinga

\begin{tabular}{lllll} 
Keadaan & \multicolumn{2}{c}{$\mathrm{n}$} & \multicolumn{2}{c}{$\%$} \\
\cline { 2 - 5 } $\begin{array}{l}\text { Liang } \\
\text { Telinga }\end{array}$ & Kanan & Kiri & Kanan & Kiri \\
\hline Lapang & 13 & 13 & 39.4 & 39.4 \\
\hline Sekret & 2 & 1 & 6.1 & 3.0 \\
\hline Serumen & 18 & 19 & 54.5 & 57.6 \\
\hline Normal & 33 & 33 & 100 & 100
\end{tabular}

c. Membran Timpani

Pada pemeriksaan membran timpani anak anak pasar bersehati komunitas dinding Manado didapatkan hasil normal telinga kanan pada 18 orang (54.5 \%) dan normal telinga kiri pada 25 orang (75.8\%). Terdapat perforasi telinga kanan sebanyak 4 orang (12.1\%) dan perforasi telinga kiri sebanyak 3 orang (9.1\%) dan membran timpani tidak dapat dievaluasi pada telinga kanan sebanyak 11 orang (33.3\%) dan pada telinga kiri sebanyak 5 orang (15.2\%). Data dapat dilihat pada tabel 3 .
Tabel 3. Distribusi hasil pemeriksaan membran timpani

\begin{tabular}{lllll}
$\begin{array}{lllll}\text { Keadaan } \\
\text { membra } \\
\text { ne } \\
\text { timpani }\end{array}$ & $\begin{array}{l}\mathrm{n} \\
\%\end{array}$ & & & \\
\cline { 2 - 5 } & kanan & kiri & kanan & kanan \\
\hline normal & 18 & 25 & 54.5 & 75.8 \\
\hline perforasi & 4 & 3 & 12.1 & 9.1 \\
\hline *tde & 11 & 5 & 33.3 & 15.2 \\
\hline total & 33 & 33 & 100 & 100 \\
& $*$ tde : tidak dapat dievaluasi &
\end{tabular}

\section{BAHASAN}

Pada penelitian anak anak pasar Bersehati Komunitas Dinding Manado ini sampel yang bersedia mengikuti penelitian sebanyak 33 orang. Berdasarkan karakteristik jenis kelamin sampel penelitian terdiri atas 19 orang perempuan (57,6\%)dan 14 orang laki-laki (42,4\%).

Berdasarkan pada hasil pemeriksaan daun telinga anak anak pasar Bersehati Manado didapatkan semua normal dan tidak ada kelainan yang didapatkan baik pada telinga kiri maupun telinga kanan.

Kemudian pada pemeriksaan liang telinga didapatkan hasil terbanyak adalah serumen pada 18 orang di telinga kanan dan serumen telinga kiri sebanyak 19 orang. Juga didapatkan liang telinga kanan maupun kiri yang lapang pada 13 orang. Serumen secara normal memang dapat ditemukan pada telinga. Serumen memiliki fungsi proteksi. Serumen ini dapat mengumpul dan membentuk massa serumen obsturan yang dapat menyumbat liang telinga. Berbagai faktor berkaitan dalam pembentukan serumen yaitu faktor internal seperti kelainan bentuk anatomis liang telinga, sekret serumen berlebihan, kelainan sistemik, aktifitas bakteri dan jamur dalam liang telinga berperan dalam pembentukan serumen obsturan. Faktor eksternal seperti cara membersihkan liang telinga, kelembaban udara yang tinggi, serta lingkungan yang berdebu juga berperan dalam pembentukan serumen obsturan. ${ }^{4,5,8}$

Pada pemeriksaan pada liang telinga 
juga ditemukan adanya sekret telinga kanan pada 2 orang serta sekret telinga kiri pada 1 orang. Sekret pada liang telinga dapat berasal dari liang telinga, telinga tengah, telinga dalam dan tulang. Faktor penyebab dari sekret biasanya adalah infeksi akut telinga tengah (otitis media supuratif dan nonsupuratif) dengan perforasi membran timpani, otitis media kronik dengan perforasi membran timpani kolesteatoma atau infeksi telinga luar. ${ }^{4-7}$

Untuk pemeriksaan pada membran timpani anak anak pasar Bersehati Komunitas Dinding Manado didapatkan hasil normal telinga kanan pada 18 orang dan normal telinga kiri pada 25 orang. Pada pemeriksaan membran timpani ini ditemukan perforasi telinga kanan sebanyak 4 orang dan perforasi telinga kiri sebanyak 3 orang. Perforasi dapat disebabkan oleh karena infeksi seperti otitis media supuratif baik akut maupun kronik, kolesteatoma, barotrauma dan adanya trauma. ${ }^{4-7}$ Dari pemeriksaan ini juga terdapat beberapa orang dengan membran timpani yang tidak dapat dievaluasi. Membran timpani yang tidak dapat dievaluasi pada telinga kanan sebanyak 11 orang dan pada telinga kiri sebanyak 5 orang. Membran timpani tidak dapat dievaluasi mungkin karena adanya serumen prop, liang telinga yang sempit dan sikap kooperatif dari sampel atau responden penelitian.

\section{SIMPULAN}

Dari keseluruhan pemeriksaan kesehatan telinga pada anak Anak Pasar Bersehati Komunitas Dinding Manado data menunjukkan sebagian besar normal walaupun penemuan serumen pada telinga masih cukup banyak, disertai penemuan lain seperti sekret pada liang telinga dan adanya perforasi pada membran timpani

\section{SARAN}

Dibutuhkan penelitian lanjutan untuk menilai faktor-faktor yang menyebabkan pembentukan serumen, sekret dan perforasi serta cara penanganan yang tepat dan efisien perlu dilakukan untuk mengurangi angka insidensi. Penemuan hasil pemeriksaan seperti sekret liang telinga dan adanya perforasi pada membran timpani diperlukan edukasi pada orang tua untuk pemeriksaan serta penanganan yang lebih lanjut di fasilitas kesehatan yang lebih lengkap kemudian peran serta orangtua dan komunitas dalam pemberian motivasi, pengetahuan perilaku hidup bersih terutama pada kesehatan telinga dan pendengaran perlu ditingkatkan.

\section{DAFTAR PUSTAKA}

1. Kementerian Kesehatan Republik Indonesia. Telinga Sehat Pendengaran Baik.2014[cited 2014 nov 20]. Available From: Http://Www.Depkes.Go.Id/Index.Php /Berita/Press-Release/840-TelingaSehatpendengaran- Baik.Html

2. Keputusan Menteri Kesehatan Republik Indonesia No. 879/Menkes/Sk/Xi/2006 Tentang Rencana Strategi Nasional Penanggulangan Gangguan Pendengaran Dan Ketulian Untuk Mencapai Sound Hearing 2030

3. Profil Komunitas Dinding Manado [cited 2014 des 2]. Available from:www.dindingmanado.com

4. Hafil AF, Sosialisman, Helmi. Kelainan telinga luar. Dalam: Soepardi EA, Iskandar N, Bashiruddin J, Restuti RD, editors. Buku Ajar Ilmu Penyakit THT (edisi 6). Jakarta : Balai penerbit FKUI, 2007. hal. 57-63

5. Boies LR, penyakit telinga luar. Dalam: Efendi H, Santoso RAK.editors. Boeis buku ajar penyakit THT (edisi 6). Jakarta : EGC,1997. hal. 75-87

6. Djaafar ZA, Helmi, Restuti RD. Kelainan telinga tengah. Dalam: Soepardi EA, Iskandar N, Bashiruddin J, Restuti RD, editors. Buku Ajar Ilmu Penyakit THT (edisi 6). Jakarta : Balai penerbit FKUI, 2007. hal. 64-77

7. Paparella MM, Adams GL, Levine SC. Penyakit telinga tengah dan mastoid. Dalam: Efendi H, Santoso RAK. editors. Boeis buku ajar penyakit THT (edisi 6). Jakarta : EGC,1997. hal. 88-105

8. Alriyanto, C. Yuniardi. Pengaruh Serumen 
Jurnal e-Clinic (eCl), Volume 3, Nomor 1, Januari-April 2015

Obsturan Terhadap Gangguan

[skripsi]. Universitas Diponegoro.

Pendengaran (Studi Kasus Pada 2010.

Siswa Kelas V Sd Di Kota Semarang 